With its American connotations the chapters dealing with the personnel function of management is of least relevance to British industry; the rest of the book could be used by any manager in a British firm wishing to improve his knowledge of particular functions or to strengthen his grasp of management as a whole. Lundy deserves high praise for the lucid way in which he has presented so many topics so authoritatively in such a short space.

Of the third reason which makes this book so remarkable little need be said. Until management is taken seriously as a subject worthy of study in graduate and postgraduate courses at universities, British text-books will continue to be written by men who are academically and intellectually inadequate. We have no comparable book to this in Britain; the need grows greater daily.

T. H. Hawkins

\section{EVERYMAN'S PARASITOLOGY}

\section{Animals Parasitic in Man}

By Dr. Geoffrey Lapage. (Pelican Book No. A394.) Pp. $320+8$ plates. (Harmondsworth, Mddx. : Ponguin Books, Ltd., 1957.) $5 s$.

$\mathrm{T}$

HERE is a deplorable lack of knowledge and much prejudice among the general public about the parasites afflicting mankind, and even the medical man, who is expected to treat the diseases caused by them, is not much better off, owing to the neglect of parasitology in the medical curriculum. The publishers and editors of the Pelican Medical Series have therefore performed a valuable service in producing a book on this subject written by a well. known parasitologist of wide experience and erudition. As stated in the foreword and preface, this book is intended for a wide range of readers, including not only educated laymen but also junior and senior members of the medical profession, as well as biologists in general.

Instead of a conventional systematic account of the animal parasites, the author has dealt with the subject in a comparative way, from the point of view of the gradual complication of their life-cycles and the patterns of host-parasite relations. This method of approach provides the reader with an evolutionary background to the natural history of parasitic infections.

In an introductory chapter the author defines the concept of parasitism in its various manifestations. In the next chapter a brief account is given of the main zoological subdivisions to which the animal parasites belong, followed by a discussion of different types of life-histories, hosts and modes of transmission of the infections. The following five chapters are devoted to parasites with monogenetic, digenetic and polygenetic life-eycles, comprising helminths and protozoa, the bionomics, structure and host-parasite relations of which are deseribed in some detail. Separate chapters are allocated to malaria parasites and trypanosomes and the diseases caused by them, while in another an account is given of animals parasitic in or on the skin (fleas, lice, fly maggots and mites) and of blood-suckers, such as biting insects and ticks, as well as leeches and bats. In each case, essential anatomical structures of the parasite, its course of development and method of transmission, as well as its effect upon the host, are adequately described. Important foatures of this book are the illustrations and diagrams, which-with the appropriate captions--give a clear picture of the lifehistories and bionomics of the parasites described in the text.

In the last two chapters Dr. Lapage considers the effect of a parasitic life upon the pathogens and the reactions of the host to infection (resistance and immunity), and winds up with a short discourse on the methods of control of infections.

The author has succeeded admirably in the task of providing an instructive and stimulating book suitable for every type of reader : to the non-scientist it opens a new and fascinating field of knowledge, while the medical man and biologist are introduced to the essentials of parasitology, and even the professional parasitologist will find it useful as a 'refresher'. Unlike some other writers of popular science books, Dr. Lapage has avoided vulgarization, for, although written in simple non-technical language, which can be understood by the non-initiated reader, the biologist can rest assured that the recognized scientific terminology and the exact zoological nomenclature are adhered to throughout the text.

Those readers whose interest has been sufficiently aroused will find at the end of the book a useful list of references for further reading. There is also a detailed subject-index of about fourteen pages.

It is to be hoped that this book will meet with the success it deserves. Last-but not least--to have produced a book of such high quality at such a low price is an achievement of which the publisher's can be justly proud.

C. A. Hoare

\section{HISTO-PATHOLOGY}

\section{Histological Technique for Normal and Pathological Tissues and the Identification of Parasites}

By H. M. Carleton, with the collaboration of R. A. B. Drury. Third edition. (Oxford Medical Publications.) Pp. xvi +343 . (London: Oxford University Press, 1957.) 30s. net.

$\mathrm{T}$

HIS is the third edition of the late H. M. Carleton's useful book on histological technique. It contains not only straight histological technique, but also many current pathological and parasitological methods. All the methods in the book have been carefully tried by either Carleton or R. A. B. Drury ; the latter collaborated especially in histo-pathological and bacteriological methods, and techniques for spirochretes. This edition contains fifty-five fewer pages than the first (1926), and yet covers the modern ground very well indeed. Carleton and Drury's book is the only work of this kind in the English language, because of the special parts of the biological field it covers. It is excellent for the zoologist, eytologist and parasitologist to have at his disposal a small volume of this kind, and there is no doubt that it will stimulate the younger workers to try techniques outside their fields. From this point of view-and it is what Carleton intended-the book should be most helpful in the coming years. For the small laboratory, for science laboratories in schools, and for poople who have to work in laboratories abroad, this book is warmly recommended.

How far such books will survive in the future, with the impact of electron microscope technique, is 